\title{
UNIVERSITY CAPACITY TO RAISE PUBLIC AWARENESS OF MEASURES TO COMBAT COVID 19: A RUSSIAN UNIVERSITY EXPERIENCE
}

\author{
Rimma Gorbatenko \\ Assistant Professor, RUDN University, Law Institute Foreign Languages Department \\ RUSSIAN FEDERATION, gorbatenko.rimma@bk.ru
}

\begin{abstract}
The goal of the paper to explore the university capacity to contribute to the public good during the current health emergency.

The above statement is explored in the paper with regard to the Peoples' Friendship University of Russia (Moscow, Russian Federation).

The research materials include open mass media sources where the academic faculty of the University provide their comments and expert opinions.

The research design integrated the analysis of academic papers to shape the research theoretical background and empirical studies. They stood on the ground theory approach and inductive techniques to aggregate the concrete items of data through context- based search of the relevant information.

The research findings reveal that in two months of strict quarantine, RUDN University doctors gave 16 interviews to the country's leading TV channels and print media about the forecast of the pandemic in Russia, the nature coronavirus infection in different countries and in different people, analysis of drugs that suppress coronavirus and methods of treatment, the special danger of coronavirus for smokers, the need for proper nutrition in a pandemic, the importance of special attention to the health of pregnant women and the need for constant attention to the psychological state and behavior of children, etc.

Further, the university volunteering activities contributed both to the public support in general, and fostered youth sustainability, as well.

The above data leads to the conclusion the university community realizes the importance of its social mission for satisfying the information needs of the population, understands the importance of applied research that really helps people in emergency situations.
\end{abstract}

Keywords: COVID 19, University engagement, university mission for public good.

\section{INTRODUCTION}

The COVID 19 has radically changed the contemporary international community life. Drastic shifts take place in economy, social life, human perception of reality, values and assets. Education in general, and higher education as well, undergo considerable restructuring in terms of curricula design, campus life and infrastructure maintenance.

Meanwhile, this period has become a kind of test for the modern civilization in terms of its operational activities, national authorities and communities responses to emerging needs and threats.

Among other issues, universities have come to light as institutions that play a comprehensive role in the 
youth and the overall society sustainable development.

This statement refers to the support for students and teachers in terms of their teaching/learning activities, financial stability, health and psychological support.

Moreover, universities have proved their focus on the contribution to public awareness raising activities within the current pandemics (Atabekova, 2020).

It refers to the university experts' engagement in the research (Fanelli, et al., 2020; Lavazza, Farina,2020; Ehrlich et al., 2020;), university students volunteering activities (Kratochvil et al., 2020; Kamarianos et al., 2020; Zheng, 2020), the work of university professors of medicine in hospitals and for on-line help lines (Hewitt, Loring, 2020; Roy, Ayalon, 2020; Trautwein, et al., 2020).

The goal of the paper to explore the trend in Russia with regard to the above-mentioned international practices.

The aim is implemented in the paper with regard to the Peoples' Friendship University of Russia (Moscow, Russian Federation).

The research materials include open mass media sources where the academic faculty of the University provide their comments and expert opinions.

The research design integrated the analysis of academic papers to shape the research theoretical background and empirical studies. They stood on the ground theory approach and inductive techniques to aggregate the concrete items of data through context- based search of the relevant information.

\section{EMPIRICAL FINDINGS}

The empirical data reveals that university consistently supported the interviews of the university professors of medicine who during the outbreak of COVID 19 in March-April 2020 shared their knowledge and research findings with the public mass media.

The interviews of university professors on the COVID 19-related topics have been accumulated on the specific web-page of the University web-platform segment on the current pandemics (RUDN Experts' Comments in mass media, $\mathrm{n} / \mathrm{d}$ ).

The content analysis of the interviews makes it possible to list the major topics that the RUDN experts covered during the lockdown period in Moscow. These topics avoid specific scientific terminology and highlight in plain language those major topics and areas which require people's attention during the pandemic.

The list bellow introduces the most discussed themes.

The difference between past and present viruses ( What is the difference between COVID-19 и SARSCoV-2, 2020)

The symptoms of COVID 19 and its pick ( Symptoms of COVID 19 and its pick, 2020)

The issues of COVID 19 patients' treatment ( Analysis of medicines that can be used to combat against COVID 19, 2020; Use of plasma for treatment of COVID 19 patients, 2020)

$\square$ Recommendations with regard to behavior in public places during the COVID 19 (On the required social distancing within diverse viruses spread, 2020)

Protective measure for pregnant and newly born babies (Advice to pregnant women and their born babies amidst COVID 19, 2020)

$\square$ Need for the diets' maintenance during the COVID 19 (We should not forget about the right eating regimes, 2020)

$\square$ Danger of smoking hobby during the COVID (the doctor told how terrible coronavirus is for smokers, 2020).

The publication of such expert opinions and information in the national media strengthens the connection between science and society as a whole, testifies to the relevance of research and the practical value of the work of university professors.

Next, it should be underlined that during the pandemic it seems critical to engage the universities in activities which aim to support the societal activities, and satisfy the public needs. 
Thus, since the very beginning the RUDN University joined the \#мейкерыпротивковид (makers against Covid) movement that tried to help solve emerging needs and tasks of the population that faced unprecedent health emergency.

In spring 2020 amid COVID 19 sharp increase, the country faced the shortage of adapters for mask filters due to unexpected number of COBID 19 patients and doctors who needed the respective masks.

Mark Dyachenko, a 23 year old engineer of the Center for Additive and Foreign Technologies of RUDN University used a 3D-printer to print 1,149 adapters for mask filters, which further were sent to over 15 Moscow hospitals.

The launch of production required just one day. Adapters of the necessary characteristics were made from certified medical plastic. 400 adapters of the required parameters were printed per day.

Most of the design and logistics operations were performed in a remote way. (The story of how it took one 23-year-old engineer a day to remake swimming masks into medical, 2020). Similar stories took part across the continents (Attaran, 2020, Erickson et al., 2020).

The direct involvement of university representatives in specific activities against COVID19 is also very important.

Specialists of the medical faculty of RUDN University worked together with students in hospitals, student volunteers helped university teachers who provided remote teaching, and students who stayed in campus on self-isolation regime.

Theses activities correlate with the above-mentioned international practices.

\section{DISCUSSION}

The empirical data reveals that university consistently supported the interviews of the university professors of medicine who during the outbreak of COVID 19 in March-April 2020 shared their knowledge and research findings with the public mass media.

The interviews of university professors on the COVID 19-related topics have been accumulated on the specific web-page of the University web-platform segment on the current pandemics (RUDN Experts' Comments in mass media, $n / d$ ).

Such activities go in line with the concept of the university three missions. They have been specified within a global ranking of higher education institutions developed by the Association of Russian Ranking Compilers with the participation of the international association IREG Observatory on Academic Ranking and Excellence.

Universities in the ranking are ranked by the quality of education, the level of scientific work, as well as by the contribution of universities to the life of society (the latter criterion is not common among other world rankings of universities).

To our mind it consistently enhances the concept of university comprehensive excellence (Atabekova et al., 2016, Stone, 2019).

To our mind, the current pandemic has produced an impact on the discussion of the university role in fostering and developing public good (Tonon, 2020).

Universities across the world have showed common features of the respective promising practices. The university activities that are aimed to raise public awareness of the situation in the country during the health emergencies contribute to fostering the university education internationalization (Atabekova, 2016; Rosyidah, 2020), foster the youth sustainability during the pandemic (Atabekova, 2020),

\section{CONCLUDING REMARKS}

The above data leads to the conclusion that in the period of health emergencies the expert opinion of representatives of the university professors and its academic community on the necessary preventive measures, treatment protocols, general recommendations for maintaining health should be heard.

Such material testifies to the fact that the university community realizes the importance of its social mission for satisfying the information needs of the population, understands the importance of applied research that really helps people in emergency situations. 


\section{REFERENCE LIST}

Advice to pregnant women and their born babies amidst COVID 19 (2020, April 3). Izvestia, https://iz.ru/994805/mariia-nediuk-anna-urmantceva/roditsia-v-korone-kak-sars-cov-2-peredaetsia-otmateri-k-rebenku

Analysis of medicines that can be used to combat against COVID 19 (2020, April 14). NTV channel. https://www.ntv.ru/novosti/2320862

Atabekova, A. (2020). University Discourse to Foster Youth's Sustainability in Society amidst COVID19: International and Russian Features. Sustainability, 12, 7336.

Atabekova, A. (2016). Fostering Internationalization at Home through Non-formal Learning. In 8th International Conference on Education and New Learning Technologies (EDULEARN 16). Barcelona, Spain, July 04-06, 2638-2642.

Atabekova, A., Belousov, A. Shoustikova, T. (2016). Vernacular and Foreign Languages in Higher Education as Driving Tools for International University Academic Excellence. ADVED $2^{\text {nd }}$ International Conference on Advances in Education and Social Sciences. Istanbul, Turkey, October 10-12, 554558.

Attaran, M. (2020). 3D Printing Role in Filling the Critical Gap in the Medical Supply Chain during COVID-19 Pandemic. American Journal of Industrial and Business Management, 10(05), 988.

Ehrlich, H., McKenney, M., \& Elkbuli, A. (2020). We Asked the Experts: Virtual Learning in Surgical Education During the COVID-19 Pandemic-Shaping the Future of Surgical Education and Training. World Journal of Surgery, 1.

Erickson, M. M., Richardson, E. S., Hernandez, N. M., Bobbert II, D. W., Gall, K., \& Fearis, P. (2020). Helmet modification to PPE With 3D printing during the COVID-19 Pandemic at Duke University Medical Center: A novel technique. The Journal of Arthroplasty.

Fanelli, S., Lanza, G., Francesconi, A., \& Zangrandi, A. (2020). Facing the Pandemic: The Italian Experience From Health Management Experts' Perspective. The American Review of Public Administration, 50(67), 753-761.

Hewitt, K. C., \& Loring, D. W. (2020). Emory university telehealth neuropsychology development and implementation in response to the COVID-19 pandemic. The Clinical Neuropsychologist, 34(7-8), 1352-1366.

Kamarianos, I., Adamopoulou, A., Lambropoulos, H., \& Stamelos, G. (2020). TOWARDS AN UNDERSTANDING OF UNIVERSITY STUDENTS'RESPONSE IN TIMES OF PANDEMIC CRISIS (COVID-19). European Journal of Education Studies, 7(7).

Kratochvil, T. J., Khazanchi, R., Sass, R. M., \& Caverzagie, K. J. (2020). Aligning student-led initiatives and Incident Command System resources in a pandemic. Medical education.

Lavazza, A., \& Farina, M. (2020). The role of experts in the Covid-19 pandemic and the limits of their epistemic authority in democracy. Frontiers in public health, 8.

On the required social distancing within diverse viruses spread (2020, March 30). Arguments and Facts. https://aif.ru/health/life/kakoe_rasstoyanie_nado_vyderzhivat_chtoby_ne_zarazitsya_virusom

Rosyidah, N. (2020). Internationalization in Higher Education: University's Effective Promotion Strategies in Building International Trust. European Journal of Educational Research, 9(1), 351-361.

Roy, S., \& Ayalon, L. (2020). "Goodness and Kindness": Long-Distance Caregiving Through Volunteers During the COVID-19 Lockdown in India. The Journals of Gerontology: Series B.

RUDN Experts' Comments in mass media (n/d) https://covid-19.rudn.ru/smi.html

Stone, L. (Ed.). (2019). The University in Society, Volume I: Oxford and Cambridge from the 14th to the Early 19th Century. Princeton University Press.

Symptoms of COVID 19 and its pick ( 2020, April 14). RBC. https://www.rbc.ru/rbcfreenews/5e94aa129a7947d1a7b4cefa

The doctor told how terrible coronavirus is for smokers ( 2020, April 14 ). Star TV 
Channel.https://tvzvezda.ru/news/vstrane_i_mire/content/2020414450-ktAkS.html

The story of how it took one 23-year-old engineer a day to remake swimming masks into medical (2020, May 29).http://eng.rudn.ru/media/news/science/the-story-of-how-it-took-one-23-year-old-engineer-a-day-toremake-swimming-masks-into-medical/

Tonon, G. (2020). The new role of the university in community development. In Research Handbook on Community Development. Edward Elgar Publishing.

Trautwein, S., Liberatore, F., Lindenmeier, J., \& von Schnurbein, G. (2020). Satisfaction with informal volunteering during the COVID-19 crisis: An empirical study considering a Swiss online volunteering platform. Nonprofit and Voluntary Sector Quarterly, 0899764020964595.

Use of plasma for treatment of COVID 19 patients ( 2020, April 9) REN TV channel. https://www.ntv.ru/novosti/2320862

We should not forget about the right eating regimes (2020, April 10).Politexpert. https://politexpert.net/192126-medik-rasskazala-kak-borotsya-s-zakisleniem-organizma-vo-vremyasamoizolyacii

What is the difference between COVID-19 и SARS-CoV-2 (2020, April 22). Indicator. https://indicator.ru/medicine/nauke-i-medicine-seichas-kraine-vazhno-vyigrat-vremya.htm

Zheng, Y. (2020). Mobilizing foreign language students for multilingual crisis translation in Shanghai. Multilingua, 1(ahead-of-print). 